\title{
LINKING TINNITUS HANDICAP INVENTORY - THI WITH THE INTERNATIONAL CLASSIFICATION OF FUNCTIONALITY, DISABILITY AND HEALTH - ICF: AN \\ EXPLORATORY STUDY FOR THE APPLICATION OF THE LINKING RULES OF THE WORLD HEALTH ORGANIZATION
}

\author{
Scheila Farias de Paiva ${ }^{1}$
}

Submitted on: 06/01/2021

Approved on: 22/06/2021

e25410

\begin{abstract}
The International Classification of Functioning, Disability and Health - ICF is an important instrument to describe the functionality of people with tinnitus. The Tinnitus Handicap Inventory (THI), an instrument for the characterization and quantification of tinnitus, and due to its practicality and diverse application possibilities, has already been translated into several languages. This qualitative, descriptive, and exploratory study intends to present the application of the THI linkage rules with the ICF, and to propose the improvement of techniques for interpretation of results, preparation of reports and multidisciplinary therapeutic planning according to the perspective and domains established by the ICF for use clinical and occupational.
\end{abstract}

KEYWORDS: CIF. Tinnitus. Connection Rules. Functionality. Disability

\section{Introduction}

Assessing the impact of tinnitus on quality of life is essential for effective treatment with the patient. The Tinnitus Handicap Inventory (THI), an instrument for the characterization and quantification of tinnitus, and due to its practicality and diverse application possibilities, has already been translated into several languages. The instrument is of great value for helping to assess and determine the degree of severity of tinnitus, as well as for characterizing and quantifying its impact on the patient's quality of life through questions that assess three dimensions: functional, emotional and catastrophic reactions to the tinnitus ${ }^{1}$.

The International Classification of Functioning, Disability and Health (ICF) is an important instrument to describe human functionality and disability. Its proposal prioritizes evaluating the impact of the symptom/pathology on the subject's functional life and not only his/her attention to the disease. From it, it is possible to describe the impact of tinnitus on a person's life, as well as its consequences on their functionality. The biopsychosocial model promoted by the ICF enables reflection on a multidimensional care approach, as well as the organization of health data as important information².

The ICF represents an advance in the classification of disabilities, by allowing a variety of uses, including in the health area, with implications and direct use in social security policy and the formulation of public policies. In addition to adding the possibility of changing the health paradigm, it modifies the form of care, previously restricted to the causality of diseases, to consider its impact on people's quality of life ${ }^{3,4}$

\footnotetext{
${ }^{1}$ Professor at the Department of Speech Therapy at the Federal University of Sergipe -UFS

Postgraduate Program at the Federal University of Juiz de Fora - UFJF
} 
LINKING TINNITUS HANDICAP INVENTORY - THI WITH THE INTERNATIONAL CLASSIFICATION OF FUNCTIONALITY, DISABILITY AND HEALTH ICF: AN EXPLORATORY STUDY FOR THE APPLICATION OF THE LINKING RULES OF THE WORLD HEALTH ORGANIZATION
Scheila Farias de Paiva

The objective of the ICF is to provide a unified and standardized language as a system for the description of health and health-related states, allowing the comparison of data relating to these conditions between countries, services, health care sectors, as well as the monitoring of its evolution over ${ }^{5}$ Despite its great relevance and being considered a public health issue, there is still no clarity about which aspects of tinnitus are more relevant in research and, therefore, there is no consensus on the most appropriate domains and instruments for its research.

According to ICF, bodily functions involve physiological or psychological functions related to human body systems; while body structures are anatomical parts of the human body such as organs, limbs and other components. Changes in function or body structure, on the other hand, are described as deficiencies, such as a deviation or significant losses. Functionality Classification refers to information about all structures and functions of the body, but added to performance in tasks or actions. In contrast, disability is a generic term for disabilities and is related to activity limitations and participation restrictions. In addition to these, it is important to highlight the interference of environmental factors that interact with all the other aspects mentioned above in a dynamic way in all dimensions ${ }^{6}$.

The process of linking clinical assessment instruments to the components of the ICF is called "Linking Rules". This process is considered one of the practical possibilities to bring health professionals closer to a clinical practice based on the biopsychosocial model. However, studies highlight that in order to link the components of the ICF with instruments, it is necessary to know, in addition to the model and the ICF, the recommendations proposed by the World Health Organization - WHO specifically to guide this ${ }^{7}$.

This exploratory study aimed to present a viable and practical proposal for linking the $\mathrm{THI}$ and the components of the ICF, in order to assist in the Functionality Classification of people with Tinnitus, preserving the originality, proposal and psychometric properties of the instrument built by Newman et al. $(1996)^{8}$.

\section{Method and Results}

This research is descriptive bibliographic type, with a qualitative approach and exploratory character. The proposal consists in applying the rules of connection between the ICF and clinical practice instruments, in this case between the Tinnitus Handicap Inventory - THI in the Brazilian Portuguese version and the International Classification of Functioning, Disability and Health - ICF also in the Brazilian Portuguese version9 .

The first stage of the connection process was carried out according to the guidelines of the reference methodological guide10. The THI information was extracted and registered in a table with all the results of the linking process (Table 1).

In the second stage, after selecting the codes for each of the 25 items, codes were also selected to represent and classify the score of each subscale. This selection took place in accordance with the guidelines of Annexes 2 and 3 of the ICF. The extraction of the content and selection of codes for the subscales, as well as the linking of the results with the qualifiers, were also registered in table 2 .

To verify the degree of agreement of the selected codes with the link proposed by James (2018)11, an inter-examiner reliability analysis was performed using the Cohens Kappa coefficient as recommended by the linking rules. The Kappa correlation coefficient varies between 0 and 1, where 0 indicates no agreement and 1 indicates perfect agreement. This test is often indicated in the literature as the ideal test to assess the degree of agreement among 
LINKING TINNITUS HANDICAP INVENTORY - THI WITH THE INTERNATIONAL CLASSIFICATION OF FUNCTIONALITY, DISABILITY AND HEALTH ICF: AN EXPLORATORY STUDY FOR THE APPLICATION OF THE LINKING RULES OF THE WORLD HEALTH ORGANIZATION Scheila Farias de Paiva

professionals in identifying significant concepts and in linking these concepts with the ICF categories12.

Statistical analysis was performed with SPSS 22.0 software and obtained a highly significant result with a value of $k=0.91$, with no missing data in the comparison between the two results. This result demonstrates that this proposal is as reliable as James' proposal11 with regard to linking the 25 items, as the author restricted himself to identifying the items individually, and it is still necessary to carry out the proposal for linking the subscales using the qualifiers for the effective classification of the impact with regard to the three domains assessed by the scale.

In the third stage, the selected codes were transported to the THI instrument, in order to identify each item linked to the ICF. Identification columns were created as an interface for identifying both the items and the results. Still as an interface for linking the results, a table was created to classify the subscale codes and the general score with their respective qualifiers, plus a specific space for the conclusion of the results (Table 3). More information about the linkage proposal will be provided below.

\section{Linking Rules with the ICF}

The use of the International Classification of Functionality in conjunction with clinical practice tools is highly recommended. Linking instruments with the ICF is a way of valuing the information already collected by the professional, mapping and complementing processed information and, at the same time, encouraging professionals to select the construction of more appropriate instruments for their clinical practice. However, sometimes, due to lack of mastery of the proposal, these tools are used from a completely different perspective from their proposal with the biopsychosocial model and remain anchored in a biomedical health model, despite including data on social participation and environmental conditions. Approaches only from this perspective result in decontextualized practices, strictly focused on interventions and monitoring only of signs and symptoms 12 .

To correctly guide this procedure, a methodological guide was published in order to avoid diversified practices. For this reason, in 2002 the first proposals for the connection rules were presented, which were updated in 2005 and refined in 2016 by Cieza10. Among the main guidelines, the need to identify the main proposal of the information to be linked is highlighted before identifying the significant concept. The rules propose much more than just identifying a significant concept, but also separating the content of the item as the main concept and additional concepts, according to the proposal and perspective of the information to be connected with the ICF. The recommendation to link the content of the instruments with the ICF, so that the ICF is the tool capable of translating the information contained in the instruments and not the other way around. Associating validated instruments with the ICF categories is not an easy task, however, international efforts have been applied to assist researchers in this process. The use of the ICF equips professionals in clinical practice, and its use can help in the selection and construction of instruments that use more accurate content.

Linking ICF content with clinical practice instruments can contribute to the operationalization of an expanded concept of health, allowing the same degree of importance to be attributed to psychological components and contextual factors, considering privileging their interaction as a health product and producer and its related states. 
LINKING TINNITUS HANDICAP INVENTORY - THI WITH THE INTERNATIONAL CLASSIFICATION OF FUNCTIONALITY, DISABILITY AND HEALTH ICF: AN EXPLORATORY STUDY FOR THE APPLICATION OF THE LINKING RULES OF THE WORLD HEALTH ORGANIZATION Scheila Farias de Paiva

The publication of the latest linkage rules intends to maximize the transparency and reliability of the process between the instrument's content and the components, and for this, improvements were proposed that highlight the need for a thorough understanding of the instrument, the model and taxonomic foundations of the ICF. Another guideline currently advocated is regarding the process of documenting the perspective contained in data collection and the category of responses (frequency, intensity, duration...) to relate the concepts involved in the responses as well.

Cieza et al. 201610, guides the realization of a detailed description in the elaboration of the linking document, since it is necessary for the process of linking the information to describe the perspective analyzed at the time of linking the categories. The recommendation of a list of ICF categories addressed is reinforced (Annex 1 ) and the record of the perspectives from which the information was collected, and specifically in the context of instruments or assessments, also in the approaches taken to categorize response options. The author emphasizes that the information will provide specialists, professionals and researchers with a more comprehensive and informed view to decide whether health information is comparable or not, if it is comparable with the perspective and categorization, in principle it is considered adequate for aggregation and quantitative comparison. In this way, the character of standardization and unification of the language by the ICF can be strengthened and fulfill its objective.

Although the linking process can be applied to any category of health information, it is not always feasible to link certain information to a specific ICF category. This occurs with information that we intend to link, but they are and in extreme opposites (beyond the scope of the ICF or too specific to be covered by the alphanumeric code). The practice suggested in publications that guide the bonding process in 2002 and 200510 refers to the use of the abbreviation nc (not covered) as a possibility at the time of decision in challenging cases for the ligament. In this study it was not necessary to use this resource, all 25 items and subscales were coded. The non-coding of the result for the general score is not due to the absence of an adequate code, but to the understanding of functionality as a complex construct and, consequently, composed of the sum of the codes of the subscales, the domains of the THI, as we will discuss later.

\section{Tinnitus Hadicap Inventory - THI}

Currently, we can find different translations of THI for the Brazilian Portuguese version. The oldest, published by Ferreria et al. in 2005, followed by two more publications, the first of these being presented by Dias, Cordeiro and Corrente and the other by Schimidt et al. also in 2006. All three versions were analyzed together with the original version of the instrument8. Then, a synthesis of the content was extracted, its connection with the components of the ICF for each item of the scale, as well as for the score of each subscale and their respective qualifiers (Chart 1 and 2). The selection of components for each item was identified in a column in the Ferreria (2005) version. The attached version was selected as the first publication in the language, as well as being mentioned by the original author of the scale in one of the international reference documents that also make up this work (Appendix 2),

Regarding psychometric properties, the THI showed high correlations between items involving boredom, sleep disturbance, depression and concentration. This is one of the findings that suggests adequate construct validity for those disabling reactions resulting from tinnitus. The symptoms distributed in the instrument's subscales represented $45 \%$ to $52 \%$ of the variance in 
LINKING TINNITUS HANDICAP INVENTORY - THI WITH THE INTERNATIONAL CLASSIFICATION OF FUNCTIONALITY, DISABILITY AND HEALTH ICF: AN EXPLORATORY STUDY FOR THE APPLICATION OF THE LINKING RULES OF THE WORLD HEALTH ORGANIZATION

Scheila Farias de Paiva

the total score of the scale, which suggests the respective classification for interpretation of the instrument's general result.

The instrument consists of 25 items distributed into three subscales. The Functional Scale with 11 items and scores between 0 - 44; Emotional Scale with 9 items and a score between 0 - 36 and the Catastrophic Scale with 5 items and a score between 0 - 20. According to the guidelines for applying the rules of connection with the ICF, the main concepts and additional concepts with their respective interpretation and alphanumeric selection for each item. Given that the gathering of items from a subscale represents a domain of functionality through a specific score ( $F, E$ and $C)$, it is important to remember that each of these escores provide qualitative information about functionality while the overall scale score results, in fact, from the sum of the three domains (three subscales) and generates a score with a quantitative representation of functionality. Often the results of subscales are completely underestimated due to the overall score, which would be a complex construct. For this reason, in this linking work, we propose to link both the individual items and the domains of each subscale. In this way, there will be the possibility for the professional to individually classify each aspect or domain (qualitative analysis) and its impact on functionality (general score), regardless of a preserved functionality or some degree of disability (activity limitation or participation restriction) revealed through the final score $>50 \%$, as suggested by the distribution of variance described by the authors in the original article.

It was found that all 25 items were in the first part of the ICF referring to the concept of Functionality (positive aspect of the classification) or Disability (negative aspect of the classification). Regarding the linking of the score of each subscale, the assigned codes were also identified in the first part of the ICF and linked to a second level code, as suggested in the case of application in health research and evaluation, in Annex 2 of the ICF4. This classification proposal will be described in detail later.

The first part is composed of two components, the first Functions (FC) and Structures of the Body (EC) and the second Activities and Participation (AP) of the individual. Both are divided into four constructs that make up the assessment of functionality and disability: changes in body functions (b); changes in body structures(s); capability (executing tasks in a standard environment) (d); performance in execution (executing tasks in a habitual environment) (d). Each component has, and its respective constructs are classified through the use of qualifiers that complement a unique alphanumeric code identified by the initials of words such as $b$ (body), s (structure), d (domain) and the letter e (from English environment).

\section{Interpretation and Classification of THI Results}

As mentioned earlier, the Tinnitus Handicap Inventory was created by Newman et al. in 1996 and became one of the most used self-report measures to measure the functional impact caused by tinnitus in people's lives. In addition to also measuring the effects of treatments, the dynamic character of the THI scores enables verification of the dynamics of life related to functionality or human disability resulting from tinnitus expressed through a score obtained between 0 and 100. As it is a psychometrically robust tool, there is a consensus in the literature that the general result obtained by the instrument reveals the level of commitment proportionally to the scores presented.

Although the THI was originally published in the United States in 1996, the authors decided to make changes to the instrument's total score in 1998 and established severity categories based on calculated quartiles with the classification 0-16 without disability, 18-26 mild disability, 38-56 
moderate disability and 58-100 severe disability. In 2001, a group of British researchers proposed the reorganization of the categories based on five groups, with $0-16 \%$ considered negligible, $18-36 \%$ mild, $38-56 \%$ moderate, $58-76 \%$ severe and $78-100 \%$ catastrophic 13 . Although this classification was not originally part of the instrument, even with the maintenance of the identification of subscales, since then its classification has been exclusively linked to the quantitative interpretation of the instrument's total score over these years. This practice is reflected in the absence of identification of subscales in some translations of the instrument into other languages. In clinical practice, this habit can even generate some disregard for qualitative aspects through the importance or relationship of subscales $\mathrm{E}, \mathrm{F}$ and $\mathrm{C}$ in understanding their three-dimensionality related to the impact of tinnitus, as proposed by the instrument itself.

For Tunkel et al. (2014) classification schemes offer an approach for professionals to measure changes in treatment over time, with and without intervention. This method provides the researcher with an opportunity to assess group differences using non-parametric statistics 14 . The authors also point out that some questionnaires have been used to document problems resulting from tinnitus, as well as to measure changes in tinnitus with treatment and differ, among other things, in measurement scales for the main functions and secondary activities affected by tinnitus. Exactly from this perspective, we resume that the ICF has as its main objective the standardization and unification of the language between professionals and their areas of expertise, in order to enable the obtaining of evidence and statistical studies with international standards. For this purpose, as the name itself describes the International Classification of Functioning, it can be considered a tool that makes it possible to obtain a common language and has been recommended in official documents of international reference groups in research in the tinnitus area.

The proposal for Classification of the Functioning of people with Tinnitus is in line with the THI proposal, mainly with regard to the analysis of content in a quantitative, but also qualitative way, and enables the mapping of the aspects of the greatest impact arising from the perception of Tinnitus. Thus, by offering both quantitative and qualitative understanding of the repercussions of tinnitus, verification and understanding of the multidimensionality that makes up human functionality. The ICF also allows for more effective and efficient therapeutic planning when linked to assessment instruments such as the THI. As an official and international instrument, the ICF adopts its own classification that is premised on the universalization and equivalence of results through research and adopts as classifiers the broad classes of percentages for cases that can be used both for calibrated instruments and for other standards of measurement of impairments, capacity limitations or performance problems related to functionality. Their percentages are calibrated for different domains with reference to population patterns as percentiles.

In order to carry out this exploratory study, as well as to enable the implementation of the Linkage proposal between the results of the assessment instrument (THI) and the classification (CIF), for several reasons that will be presented below, it is suggested to use the classification of the CIF and its qualifiers for the interpretation and results obtained with the THI. The theoretical foundation and information on disability values, as well as the psychometric properties studied regardless of their link with the classifications currently used for interpretation of the general score, and use of the integral and qualitative proposal of the instrument with information offered by the respective subscales, added to the ample evidence for classification of functionality, follow the WHO recommendations for its use and, consequently, the proposal of linking the instruments. 
LINKING TINNITUS HANDICAP INVENTORY - THI WITH THE INTERNATIONAL CLASSIFICATION OF FUNCTIONALITY, DISABILITY AND HEALTH ICF: AN EXPLORATORY STUDY FOR THE APPLICATION OF THE LINKING RULES OF THE WORLD HEALTH ORGANIZATION Scheila Farias de Paiva

\section{Results Linking Process - Table Preparation (Paiva, 2021)}

\section{Alphanumeric Codes and Qualifiers}

The classification of the ICF components is carried out by the formation of an alphanumeric code that includes the presence of the qualifiers. It is important to highlight that these are only complete with the presence of at least one qualifier after the one separating point (xxx.1). This means that without the presence of a qualifier, the code completely loses its meaning.

According to $\mathrm{WHO}$, the function of the qualifier is to indicate the magnitude of the extent and severity of the problem, or the level of health. All ICF components are quantified using the same generic scale represented by:

XXX.0 No Problem (0-4\%)

XXX.1 Mild Problem (5-24\%)

XXX.2 Moderate Problem (25-49\%)

XXX.3 Serious Problem (59-95\%)

XXX.4 Complete problem (96-100\%)

XXX.8 Not specified

XXX.9 Not applicable

\section{Categorization of Subscales and use of Activity and Participation list for distinct Domain Groups without overlapping}

Regarding the categorization of the functional subscale, the d720 category was initially selected, however, it was found that Annex 3 of the ICF presents a complete list of Activity and Participation domains. It is considered that this list completely covers the range of functionality that can be encoded, both at the individual level and at the social level. Given this possibility, it was decided to use the list of Activity and Participation domains for distinct groups without overlapping. There was grouping of categories for the use of only one code for a group of categories related to Activities (a) or Participation (p). The Functional Subscale was categorized with code p7 (Interpersonal interactions), also having as a suggestion the use of p8 (Main Areas of Life), mainly for occupational assessment situations.

Regarding the description of the results, the classification words must be chosen according to the classification domain. In the specific case of the THI, we will have a qualitative result (identified of the most affected aspects from the subscales) and a quantitative result (general score).

The result of the subscales for the Emotional and Catastrophic scales correspond to body functions (b152 and b160), both reveal Functional Integrity (or without any difficulty) in case of qualifier (.0), or Deficiency for b152 (emotional functions) or b160 (thought functions), followed by the degree corresponding to the value obtained in these subscales. For the Functional Subscale $(F)$, the result corresponds to a Capacity Limitation or Performance Problem for the performance in Activities and Participation (codes p7 and p8), followed also by the degree of perceived impact. As for the classification of the overall score, it is suggested, in case of values 


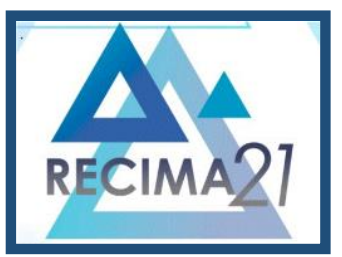

\section{RECIMA21 - REVISTA CIENTÍFICA MULTIDISCIPLINAR}

ISSN 2675-6218

LINKING TINNITUS HANDICAP INVENTORY - THI WITH THE INTERNATIONAL CLASSIFICATION OF FUNCTIONALITY, DISABILITY AND HEALTH ICF: AN EXPLORATORY STUDY FOR THE APPLICATION OF THE LINKING RULES OF THE WORLD HEALTH ORGANIZATION Scheila Farias de Paiva

between 4 and 48 , to describe the result as Preserved Functionality, but with mild (1) or moderate (2) difficulty according to the obtained result, and for results above 48 , describe as Severe (3) or Complete (4) Functional Limitation or Restriction, according to the equivalence of the result. 


\section{RECIMA21 - REVISTA CIENTÍFICA MULTIDISCIPLINAR}

ISSN 2675-6218

LINKING TINNITUS HANDICAP INVENTORY - THI WITH THE INTERNATIONAL CLASSIFICATION OF FUNCTIONALITY, DISABILITY AND HEALTH - ICF: AN EXPLORATORY STUDY FOR THE APPLICATION OF THE LINKING RULES OF THE WORLD Scheila Farias de Paiva

Table 1- Content extraction from Tinnitus Handicap Inventory - THI

\begin{tabular}{|c|c|c|c|c|c|c|c|c|c|}
\hline \multicolumn{10}{|c|}{ TINNITUS HANDICAP INVENTORY - THI } \\
\hline HEADER & ITEMS & $\begin{array}{l}\text { PERSPECTIVEDA } \\
\text { INFORMATION }\end{array}$ & $\begin{array}{l}\text { RESPONSE } \\
\text { OPTIONS }\end{array}$ & $\begin{array}{l}\text { CLASSIFICATION OF } \\
\text { RESPONSE OPTIONS }\end{array}$ & $\begin{array}{c}\text { MAIN } \\
\text { CONCEPT }\end{array}$ & $\begin{array}{l}\text { ADDITIONAL } \\
\text { CONCEPT }\end{array}$ & $\begin{array}{l}\text { CIF CATEGORY } \\
\text { MAIN CONCEPT }\end{array}$ & $\begin{array}{l}\text { CIF CATEGORY } \\
\text { FORO CONCEPT } \\
\text { ADICIONAL }\end{array}$ & $\begin{array}{l}\text { ADDITIONAL } \\
\text { INFORMATION }\end{array}$ \\
\hline $\begin{array}{l}\text { What is the } \\
\text { impact of } \\
\text { Tinnitus on the } \\
\text { patient's life? }\end{array}$ & 25 & $\begin{array}{l}\text { Assessment das } \\
\text { repercussões do } \\
\text { Tinnitus }\end{array}$ & $\begin{array}{l}\text { Yes, No ou } \\
\text { Sometimes }\end{array}$ & Frequency & $\begin{array}{l}\text { Tinnitus } \\
\text { Perception }\end{array}$ & $\begin{array}{l}\text { Uncomfortable } \\
\text { / } \\
\text { Impacto do } \\
\text { Tinnitus }\end{array}$ & $\begin{array}{l}\text { b1560 - Tinnitus } \\
\text { Perception }\end{array}$ & b2400 - Tinnitus & $\begin{array}{l}\text { Components and } \\
\text { Constructs - ICF }\end{array}$ \\
\hline HEADER & ITEMS & $\begin{array}{l}\text { PERSPECTIVE } \\
\text { INFORMATION }\end{array}$ & $\begin{array}{l}\text { RESPONSE } \\
\text { OPTIONS }\end{array}$ & $\begin{array}{l}\text { CLASSIFICATION OF } \\
\text { RESPONSE OPTIONS }\end{array}$ & $\begin{array}{c}\text { MAIN } \\
\text { CONCEPT }\end{array}$ & $\begin{array}{l}\text { ADDITIONAL } \\
\text { CONCEPT }\end{array}$ & $\begin{array}{l}\text { CIF CATEGORY } \\
\text { FORO MAIN } \\
\text { CONCEPT }\end{array}$ & $\begin{array}{l}\text { CIF CATEGORY } \\
\text { FORO CONCEPT } \\
\text { ADDITIONAL }\end{array}$ & $\begin{array}{l}\text { ADDITIONAL } \\
\text { INFORMATION }\end{array}$ \\
\hline $\begin{array}{l}\text { Functioonal } \\
\text { Subescale } \\
\text { (d720); }\end{array}$ & 1 & Assessment & $\begin{array}{l}\text { Yes, } \\
\text { No ou } \\
\text { Sometimes }\end{array}$ & Frequency & $\begin{array}{l}\text { Tinnitus } \\
\text { Perception }\end{array}$ & $\begin{array}{l}\text { Maintenance } \\
\text { of Attention }\end{array}$ & b1560 & b1400 & $\begin{array}{l}\text { Body-Body } \\
\text { Functional }\end{array}$ \\
\hline $\begin{array}{l}\text { Functioonal } \\
\text { Subescale } \\
\text { (d720); }\end{array}$ & 2 & Assessment & $\begin{array}{l}\text { Yes, } \\
\text { No ou } \\
\text { Sometimes }\end{array}$ & Frequency & $\begin{array}{l}\text { Tinnitus } \\
\text { Perception }\end{array}$ & $\begin{array}{l}\text { difficulty } \\
\text { hearing }\end{array}$ & b1560 & b230 & $\begin{array}{l}\text { Body - Body } \\
\text { Functional }\end{array}$ \\
\hline $\begin{array}{l}\text { Subscale } \\
\text { Emotional } \\
\text { (b152); }\end{array}$ & 3 & Assessment & $\begin{array}{l}\text { Yes, } \\
\text { No ou } \\
\text { Sometimes }\end{array}$ & Frequency & $\begin{array}{l}\text { Tinnitus } \\
\text { Perception }\end{array}$ & $\begin{array}{l}\text { Irritabilidade } \\
\text { Uncontrolled } \\
\text { situation } \\
\text { Emotional }\end{array}$ & b1560 & b1522 & $\begin{array}{l}\text { Body - Body } \\
\text { Functional }\end{array}$ \\
\hline $\begin{array}{l}\text { Functioonal } \\
\text { Subescale } \\
\text { (d720); }\end{array}$ & 4 & Assessment & $\begin{array}{l}\text { Yes, } \\
\text { No ou } \\
\text { Sometimes }\end{array}$ & Frequency & $\begin{array}{l}\text { Tinnitus } \\
\text { Perception }\end{array}$ & $\begin{array}{l}\text { Confusion/ } \\
\text { decision } \\
\text { making }\end{array}$ & b1560 & d177 & $\begin{array}{l}\text { Activity and } \\
\text { Participation - } \\
\text { C/D }\end{array}$ \\
\hline $\begin{array}{l}\text { Subscale } \\
\text { Catastrophic } \\
\text { (b160) }\end{array}$ & 5 & Assessment & $\begin{array}{l}\text { Yes, } \\
\text { No ou } \\
\text { Sometimes }\end{array}$ & Frequency & $\begin{array}{l}\text { Tinnitus } \\
\text { Perception }\end{array}$ & Despair & b1560 & b160 & $\begin{array}{l}\text { Body-Body } \\
\text { Functional }\end{array}$ \\
\hline $\begin{array}{l}\text { Subscale } \\
\text { Emotional } \\
\text { (b152); }\end{array}$ & 6 & Assessment & $\begin{array}{l}\text { Yes, } \\
\text { No ou } \\
\text { Sometimes }\end{array}$ & Frequency & $\begin{array}{l}\text { Tinnitus } \\
\text { Perception }\end{array}$ & Uncomfortable & b1560 & b152 & $\begin{array}{l}\text { Body - Body } \\
\text { Functional }\end{array}$ \\
\hline
\end{tabular}




\section{RECIMA21 - REVISTA CIENTÍFICA MULTIDISCIPLINAR}

ISSN 2675-6218

LINKING TINNITUS HANDICAP INVENTORY - THI WITH THE INTERNATIONAL CLASSIFICATION OF FUNCTIONALITY, DISABILITY AND HEALTH - ICF: AN EXPLORATORY STUDY FOR THE APPLICATION OF THE LINKING RULES OF THE WORLD HEALTH ORGANIZATION
Scheila Farias de Paiva

\begin{tabular}{|c|c|c|c|c|c|c|c|c|c|}
\hline $\begin{array}{l}\text { Functioonal } \\
\text { Subescale } \\
\text { (d720); }\end{array}$ & 7 & Assessment & $\begin{array}{l}\text { Yes, } \\
\text { No ou } \\
\text { Sometimes }\end{array}$ & Frequency & $\begin{array}{l}\text { Tinnitus } \\
\text { Perception }\end{array}$ & $\begin{array}{l}\text { difficulty } \\
\text { sleeping }\end{array}$ & b1560 & b134 & $\begin{array}{l}\text { Body-Body } \\
\text { Functional }\end{array}$ \\
\hline $\begin{array}{l}\text { Subscale } \\
\text { Catastrophic } \\
\text { (b160) }\end{array}$ & 8 & Assessment & $\begin{array}{l}\text { Yes, } \\
\text { No ou } \\
\text { Sometimes }\end{array}$ & Frequency & $\begin{array}{l}\text { Tinnitus } \\
\text { Perception }\end{array}$ & $\begin{array}{l}\text { Impotence / } \\
\text { Uncontrolled } \\
\text { situation/ } \\
\text { Ruminação }\end{array}$ & b1560 & b1602 & $\begin{array}{l}\text { Body - Body } \\
\text { Functional }\end{array}$ \\
\hline $\begin{array}{l}\text { Functioonal } \\
\text { Subescale } \\
\text { (d720); }\end{array}$ & 9 & Assessment & $\begin{array}{l}\text { Yes, } \\
\text { No ou } \\
\text { Sometimes }\end{array}$ & Frequency & $\begin{array}{l}\text { Tinnitus } \\
\text { Perception }\end{array}$ & Performance & b1560 & d920 & $\begin{array}{l}\text { Activity and } \\
\text { Participation - } \\
\text { C/D }\end{array}$ \\
\hline $\begin{array}{l}\text { Subscale } \\
\text { Emotional } \\
\text { (b152); }\end{array}$ & 10 & Assessment & $\begin{array}{l}\text { Yes, } \\
\text { No ou } \\
\text { Sometimes }\end{array}$ & Frequency & $\begin{array}{l}\text { Tinnitus } \\
\text { Perception }\end{array}$ & Undress & b1560 & b1520 & $\begin{array}{l}\text { Body - Body } \\
\text { Functional }\end{array}$ \\
\hline $\begin{array}{l}\text { Subscale } \\
\text { Catastrophic } \\
\text { (b160) }\end{array}$ & 11 & Assessment & $\begin{array}{l}\text { Yes, } \\
\text { No ou } \\
\text { Sometimes }\end{array}$ & Frequency & $\begin{array}{l}\text { Tinnitus } \\
\text { Perception }\end{array}$ & Despair & b1560 & b1602 & $\begin{array}{l}\text { Body - Body } \\
\text { Functional }\end{array}$ \\
\hline $\begin{array}{l}\text { Functioonal } \\
\text { Subescale } \\
\text { (d720); }\end{array}$ & 12 & Assessment & $\begin{array}{l}\text { Yes, } \\
\text { No ou } \\
\text { Sometimes }\end{array}$ & Frequency & $\begin{array}{l}\text { Tinnitus } \\
\text { Perception }\end{array}$ & $\begin{array}{l}\text { Interpersonal } \\
\text { relationships }\end{array}$ & b1560 & d9205 & $\begin{array}{l}\text { Activity and } \\
\text { Participation - } \\
\text { C/D }\end{array}$ \\
\hline $\begin{array}{l}\text { Functioonal } \\
\text { Subescale } \\
\text { (d720); }\end{array}$ & 13 & Assessment & $\begin{array}{l}\text { Yes, } \\
\text { No ou } \\
\text { Sometimes }\end{array}$ & Frequency & $\begin{array}{l}\text { Tinnitus } \\
\text { Perception }\end{array}$ & $\begin{array}{l}\text { Productivity/Co } \\
\text { ncentration }\end{array}$ & b1560 & $\mathrm{d} 8451 / \mathrm{d} 640$ & $\begin{array}{l}\text { Activity and } \\
\text { Participation - } \\
\text { C/D }\end{array}$ \\
\hline $\begin{array}{l}\text { Subscale } \\
\text { Emotional } \\
\text { (b152); }\end{array}$ & 14 & Assessment & $\begin{array}{l}\text { Yes, } \\
\text { No ou } \\
\text { Sometimes }\end{array}$ & Frequency & $\begin{array}{l}\text { Tinnitus } \\
\text { Perception }\end{array}$ & $\begin{array}{l}\text { Irritabilidade } \\
\text { Uncontrolled } \\
\text { situation } \\
\text { Emotional }\end{array}$ & b1560 & b 152 & $\begin{array}{l}\text { Body - Body } \\
\text { Functional }\end{array}$ \\
\hline $\begin{array}{l}\text { Functioonal } \\
\text { Subescale } \\
\text { (d720); }\end{array}$ & 15 & Assessment & $\begin{array}{l}\text { Yes, } \\
\text { No ou } \\
\text { Sometimes }\end{array}$ & Frequency & $\begin{array}{l}\text { Tinnitus } \\
\text { Perception }\end{array}$ & Reading Tasks & b1560 & d166 & $\begin{array}{l}\text { Activity and } \\
\text { Participation - } \\
\text { C/D }\end{array}$ \\
\hline $\begin{array}{l}\text { Subscale } \\
\text { Emotional } \\
\text { (b152); }\end{array}$ & 16 & Assessment & $\begin{array}{l}\text { Yes, } \\
\text { No ou } \\
\text { Sometimes }\end{array}$ & Frequency & $\begin{array}{l}\text { Tinnitus } \\
\text { Perception }\end{array}$ & $\begin{array}{l}\text { Indisposição/ } \\
\text { Depression }\end{array}$ & b1560 & b1522 & $\begin{array}{l}\text { Body - Body } \\
\text { Functional }\end{array}$ \\
\hline
\end{tabular}




\section{RECIMA21 - REVISTA CIENTÍFICA MULTIDISCIPLINAR}

ISSN 2675-6218

LINKING TINNITUS HANDICAP INVENTORY - THI WITH THE INTERNATIONAL CLASSIFICATION OF FUNCTIONALITY, DISABILITY AND HEALTH - ICF: AN EXPLORATORY STUDY FOR THE APPLICATION OF THE LINKING RULES OF THE WORLD HEALTH ORGANIZATION

\begin{tabular}{|c|c|c|c|c|c|c|c|c|c|}
\hline $\begin{array}{l}\text { Subscale } \\
\text { Emotional } \\
\text { (b152); }\end{array}$ & 17 & Assessment & $\begin{array}{l}\text { Yes, } \\
\text { No ou } \\
\text { Sometimes } \\
\end{array}$ & Frequency & $\begin{array}{l}\text { Tinnitus } \\
\text { Perception }\end{array}$ & $\begin{array}{l}\text { Interpersonal } \\
\text { relationships }\end{array}$ & b1560 & $d 750 / d 760$ & $\begin{array}{l}\text { Activity and } \\
\text { Participation - } \\
\text { C/D }\end{array}$ \\
\hline $\begin{array}{l}\text { Functioonal } \\
\text { Subescale } \\
\text { (d720); }\end{array}$ & 18 & Assessment & $\begin{array}{l}\text { Yes, } \\
\text { No ou } \\
\text { Sometimes }\end{array}$ & Frequency & $\begin{array}{l}\text { Tinnitus } \\
\text { Perception }\end{array}$ & $\begin{array}{l}\text { Maintenance } \\
\text { of Attention }\end{array}$ & b1560 & $\mathrm{d} 160$ & $\begin{array}{l}\text { Activity and } \\
\text { Participation - } \\
\text { C/D }\end{array}$ \\
\hline $\begin{array}{l}\text { Subscale } \\
\text { Catastrophic } \\
\text { (b160) }\end{array}$ & 19 & Assessment & $\begin{array}{l}\text { Yes, } \\
\text { No ou } \\
\text { Sometimes }\end{array}$ & Frequency & $\begin{array}{l}\text { Tinnitus } \\
\text { Perception }\end{array}$ & Lack of control & b1560 & b1521 & $\begin{array}{l}\text { Body - Body } \\
\text { Functional }\end{array}$ \\
\hline $\begin{array}{l}\text { Functioonal } \\
\text { Subescale } \\
\text { (d720); }\end{array}$ & 20 & Assessment & $\begin{array}{l}\text { Yes, } \\
\text { No ou } \\
\text { Sometimes }\end{array}$ & Frequency & $\begin{array}{l}\text { Tinnitus } \\
\text { Perception }\end{array}$ & Energy & b1560 & b130 & $\begin{array}{l}\text { Body-Body } \\
\text { Functional }\end{array}$ \\
\hline $\begin{array}{l}\text { Subscale } \\
\text { Emotional } \\
\text { (b152); }\end{array}$ & 21 & Assessment & $\begin{array}{l}\text { Yes, } \\
\text { No ou } \\
\text { Sometimes }\end{array}$ & Frequency & $\begin{array}{l}\text { Tinnitus } \\
\text { Perception }\end{array}$ & Depression & b1560 & b1521/1522 & $\begin{array}{l}\text { Body - Body } \\
\text { Functional }\end{array}$ \\
\hline $\begin{array}{l}\text { Subscale } \\
\text { Emotional } \\
\text { (b152); }\end{array}$ & 22 & Assessment & $\begin{array}{l}\text { Yes, } \\
\text { No ou } \\
\text { Sometimes }\end{array}$ & Frequency & $\begin{array}{l}\text { Tinnitus } \\
\text { Perception }\end{array}$ & Anxiety & b1560 & b1522 & $\begin{array}{l}\text { Body - Body } \\
\text { Functional }\end{array}$ \\
\hline $\begin{array}{l}\text { Subscale } \\
\text { Catastrophic } \\
\text { (b160) }\end{array}$ & 23 & Assessment & $\begin{array}{l}\text { Yes, } \\
\text { No ou } \\
\text { Sometimes }\end{array}$ & Frequency & $\begin{array}{l}\text { Tinnitus } \\
\text { Perception }\end{array}$ & $\begin{array}{l}\text { Inability e } \\
\text { Despair }\end{array}$ & b1560 & b1304 & $\begin{array}{l}\text { Body - Body } \\
\text { Functional }\end{array}$ \\
\hline $\begin{array}{l}\text { Functioonal } \\
\text { Subescale } \\
\text { (d720); }\end{array}$ & 24 & Assessment & $\begin{array}{l}\text { Yes, } \\
\text { No ou } \\
\text { Sometimes }\end{array}$ & Frequency & $\begin{array}{l}\text { Tinnitus } \\
\text { Perception }\end{array}$ & Stresse & b1560 & $\mathrm{d} 2401$ & $\begin{array}{l}\text { Activity and } \\
\text { Participation - } \\
\text { C/D }\end{array}$ \\
\hline $\begin{array}{l}\text { Subscale } \\
\text { Emotional } \\
\text { (b152); }\end{array}$ & 25 & Assessment & $\begin{array}{l}\text { Yes, } \\
\text { No ou } \\
\text { Sometimes }\end{array}$ & Frequency & $\begin{array}{l}\text { Tinnitus } \\
\text { Perception }\end{array}$ & Insecurity & b1560 & b1522 & $\begin{array}{l}\text { Body - Body } \\
\text { Functional }\end{array}$ \\
\hline
\end{tabular}

Source: Prepared by the author. 


\section{RECIMA21 - REVISTA CIENTIFICA MULTIDISCIPLINAR}

ISSN 2675-6218

LINKING TINNITUS HANDICAP INVENTORY - THI WITH THE INTERNATIONAL CLASSIFICATION OF FUNCTIONALITY, DISABILITY AND HEALTH - ICF: AN EXPLORATORY STUDY FOR THE APPLICATION OF THE LINKING RULES OF THE WORLD

Table 2- Content extraction from Results of Tinnitus Handicap Inventory - THI

\begin{tabular}{|c|c|c|c|c|c|c|c|c|c|c|}
\hline SUBSCALES & CÓDIGO & MAIN CONCEPT & $\begin{array}{l}\text { ADDITIONAL } \\
\text { CONCEPT }\end{array}$ & $\begin{array}{l}\text { ADDITIONAL } \\
\text { INFORMATION }\end{array}$ & SCORE & \multicolumn{5}{|c|}{$\begin{array}{c}\text { RESULTADOS E } \\
\text { QUALIFICADORES DA CIF }\end{array}$} \\
\hline Emotional Subescale & $\mathrm{p} 7 / \mathrm{p} 8$ & $\begin{array}{c}\text { Auditory Behavior } \\
\text { and } \\
\text { Activity/Participation }\end{array}$ & $\begin{array}{l}\text { Mental, Social and } \\
\text { Occupational } \\
\text { Disability }\end{array}$ & $\begin{array}{l}\text { Difficulty in } \\
\text { Concentration }\end{array}$ & $0-44$ & $\begin{array}{c}\mathbf{0} \\
\text { None } \\
(0-4)\end{array}$ & $\begin{array}{c}1 \\
\text { Light } \\
(6-14)\end{array}$ & $\begin{array}{c}\mathbf{2} \\
\text { Moderate } \\
(16-20)\end{array}$ & $\begin{array}{c}\mathbf{3} \\
\text { Serious } \\
(22-40)\end{array}$ & $\begin{array}{c}4 \\
\text { Complete } \\
(42-44)\end{array}$ \\
\hline Functional Subescale & b152 & Emotional Functions & $\begin{array}{l}\text { Range of Emotions } \\
\text { and Spectrum of } \\
\text { Experiences }\end{array}$ & Social Disability & $0-36$ & $\begin{array}{c}\mathbf{0} \\
\text { None } \\
(0-2) \\
\end{array}$ & $\begin{array}{c}1 \\
\text { Light } \\
(4-8) \\
\end{array}$ & $\begin{array}{c}\mathbf{2} \\
\text { Moderate } \\
(10-16) \\
\end{array}$ & $\begin{array}{c}\mathbf{3} \\
\text { Serious } \\
(18-32) \\
\end{array}$ & $\begin{array}{c}4 \\
\text { Complete } \\
(34-36) \\
\end{array}$ \\
\hline $\begin{array}{l}\text { Catastrophic } \\
\text { Subescale }\end{array}$ & b160 & Mental Functions & Disability referred & $\begin{array}{l}\text { Feelings: Anger, } \\
\text { Frustration, Irritability } \\
\text { and/or Depression }\end{array}$ & $0-20$ & $\begin{array}{c}\mathbf{0} \\
\text { None } \\
(0-2)\end{array}$ & $\begin{array}{c}1 \\
\text { Light } \\
(4-6)\end{array}$ & $\begin{array}{c}\mathbf{2} \\
\text { Moderate } \\
(8-10)\end{array}$ & $\begin{array}{c}\mathbf{3} \\
\text { Serious } \\
(12-16)\end{array}$ & $\begin{array}{c}\mathbf{4} \\
\text { Complete } \\
(18-20)\end{array}$ \\
\hline \multirow[t]{2}{*}{ Score Total } & \multirow{2}{*}{$\begin{array}{c}\text { b2400 } \\
\text { b1560/ } \\
\text { b152 } \\
\text { d720 }\end{array}$} & \multirow[t]{2}{*}{$\begin{array}{l}\text { Disability referred to } \\
\text { by Tinnitus }\end{array}$} & \multirow{2}{*}{$\begin{array}{l}\text { Tinnitus } \\
\text { repercussions on } \\
\text { complex } \\
\text { interpersonal } \\
\text { interactions }\end{array}$} & \multirow[t]{2}{*}{$\begin{array}{l}\text { Despair; lack of control; } \\
\text { Inability; Impotence }\end{array}$} & \multirow[t]{2}{*}{$0-100$} & $\begin{array}{c}0 \\
\text { None } \\
(0-4)\end{array}$ & $\begin{array}{c}1 \\
\text { Light } \\
(6-24)\end{array}$ & $\begin{array}{c}\mathbf{2} \\
\text { Moderate } \\
(24-48)\end{array}$ & $\begin{array}{c}\mathbf{3} \\
\text { Serious } \\
\text { (50-96) }\end{array}$ & $\begin{array}{c}\mathbf{4} \\
\text { Complete } \\
(96-100)\end{array}$ \\
\hline & & & & & & \multicolumn{5}{|c|}{$\begin{array}{r}\text { Result: } 0-\mathbf{4 8}=\text { Preserved Functionality }^{2} \\
\mathbf{5 0}-\mathbf{1 0 0}=\text { Disability to Tinnitus. }\end{array}$} \\
\hline
\end{tabular}

Source: Prepared by the author.

1. Regardless of the result, in the presence of discomfort with Tinnitus, the importance of the qualitative analysis offered by the subscale scores is highlighted. 


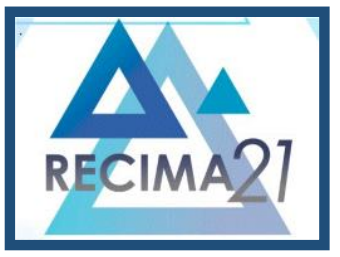

\section{RECIMA21 - REVISTA CIENTÍFICA MULTIDISCIPLINAR ISSN 2675-6218}

LINKING TINNITUS HANDICAP INVENTORY - THI WITH THE INTERNATIONAL CLASSIFICATION OF FUNCTIONALITY, DISABILITY AND HEALTH - ICF: AN EXPLORATORY STUDY FOR THE APPLICATION OF THE LINKING RULES OF THE WORLD HEALTH ORGANIZATION
Scheila Farias de Paiva

\section{LINKING TABLE OF THI RESULTS WITH CIF (PAIVA, 2021)}

\begin{tabular}{|c|c|c|c|c|c|}
\hline \multirow{2}{*}{$\begin{array}{l}\text { Classifier } \\
\text { F (p7; p8.__) }\end{array}$} & \multicolumn{5}{|c|}{ Qualifiers (Paiva, 2021) } \\
\hline & O.None (0-4) & 1.Light (6-14) & 2.Moderate (16-20) & 3. Serious (22-40) & 4. Complete (42-44) \\
\hline E (b152.__) & 0.None (0-2) & 1. Light (4-8) & 2. Moderate (10-16) & 3. Serious (18-32) & 4. Complete (34-36) \\
\hline C (b160._) & 0.None (0-2) & 1. Light (4-6) & 2. Moderate (8-10) & 3. Serious (12-16) & 4. Complete (18-20) \\
\hline Difficulty. __ & 0.None (0-4) & 1. Light (6-24) & 2. Moderate (24-48) & 3. Serious (50-96) & 4.Complete (96-100) \\
\hline \multicolumn{3}{|c|}{$\begin{array}{l}\text { Functional Integrity : } 0-4 \\
\text { Preserved Functionality : } 4-48 \\
\text { Incapacity: } 50-100\end{array}$} & \multirow{3}{*}{\multicolumn{3}{|c|}{ Conclusion: }} \\
\hline \multicolumn{3}{|c|}{$\begin{array}{l}\square \text { b230.0 Absent/Light } \square_{\text {b230.1 Moderate }} \\
\square \text { b230.2 Moderately severe ; } \quad \square \text { b230.4 Profound }\end{array}$} & & & \\
\hline \multicolumn{3}{|c|}{$\begin{array}{l}\text { Hearing Ai dor } \mathrm{Cl} \text { (e1252. _) } \\
\square \text { Facilitator (+) } \square \text { Barriers } \square \text { Not applicable } \\
\text { 0.None/ 1.Ligth/2.Moderate/3.Serious/4.Complete } \\
\text { Obs: }\end{array}$} & & & \\
\hline
\end{tabular}

Table 3 - Quantitative and qualitative classification of results

Source: Prepared by the author (Paiva, 2021)

\section{FINAL CONSIDERATIONS}

Based on the ICF interactive model, this study showed how the results of using three distinct ICF scales reflect a relationship between identified impairments and their correlated disability areas in individuals with tinnitus. These findings also suggest that the ICF classification can be used as a cardinal reference for health-related measures, where the overall score is the result of the relationship between the subscales we call severity or impact related to the annoyance of tinnitus (b1560) and should be understood in its three-dimensionality presented by Newman et. like:

1. Functional Dimension (p7/p8): Verified in the extraction of the contents that the components correspond mostly to the identified Body Functions, added to some evaluation items of the Activity and Social Participation (attached);

2. Emotional Dimension (b152): Verified in the extraction of contents that were linked to components related to Emotional Functions

3. Catastrophic Dimension (b160): Verified in the extraction of contents that were linked to components related to thought functions.

For this reason, the practical understanding that the overall result of the THI is actually the result of the functionality or incapacity of an individual revealed from the classification of the three subscales, allows a new look at the instrument and a greater understanding of the impact of tinnitus in health with regard to its multidimensionality. Thus, even with some limitations, the THI can help measure the functionality of people with tinnitus, considering that the instrument assesses aspects related to Body Functions, Activity and Participation. In addition to measuring, by linking 


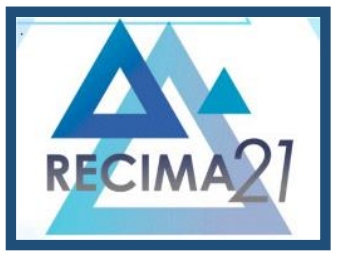

\section{RECIMA21 - REVISTA CIENTÍFICA MULTIDISCIPLINAR ISSN 2675-6218}

LINKING TINNITUS HANDICAP INVENTORY - THI WITH THE INTERNATIONAL CLASSIFICATION OF FUNCTIONALITY, DISABILITY AND HEALTH - ICF: AN EXPLORATORY STUDY FOR THE APPLICATION OF THE LINKING RULES OF THE WORLD HEALTH ORGANIZATION Scheila Farias de Paiva

the THI with the ICF biopsychosocial model, it is possible to map the most compromised aspects and suggest treatments that are more adequate to the patients' needs.

The link between the THI and the ICF and the use of its qualifiers provide an opportunity for a qualitative and quantitative look at the impact of tinnitus on people's lives, however, without restricting tinnitus to one-dimensionality, as occurs in the use of an exclusively quantitative classification of results. The linking procedure between the instruments made it possible to relate the ICF codes and qualifiers with each item of the scale independently, as well as to classify the dimensions represented by the correspondence with each of the subscales.

The reliability analysis revealed that this proposal proves to be as reliable as James' proposal11, but it presented some innovations such as the link and classification of subscales, with a new interpretation for the overall THI score. The author also emphasizes that the severity classification currently proposed is not sufficient to contemplate the activity limitation and participation restriction in tinnitus, and that complements and states that the composite scores of the assessment scales can hide the actual affected areas of tinnitus functioning. This statement corroborates the proposed interpretation of the results.

Furthermore, despite a few items to assess Activity and Participation, it is clear that the correspondence of the general result in measuring the impact of tinnitus on human functionality can be classified in its quantitative aspect as disabling when there is a superior result to $48 \%$, as suggested by the authors in the original article.

It is clear from this that the ICF structure precisely identifies the affected areas in the lives of tinnitus patients, based on which an intervention model can be prepared for application in groups and individuals. Such models act as a facilitator for symptomatic intervention, as the perceived problem due to tinnitus is a subjective factor that varies between individuals, depending on their coping and defense mechanisms used, personality traits and personal attitudes towards tinnitus.

Finally, the link between the instruments and the correct use of the classification table with their respective qualifiers, enable health professionals to prepare Occupational Reports and Reports that reflect the impact of tinnitus and its repercussions on various aspects of life, including work of people with disabilities resulting from the presence of tinnitus. It is suggested to use the THI in partnership with WHODAS 2016 when values are greater than $48 \%$ and that other studies based on the same proposal be carried out to verify, refine and validate this proposal as an alternative for interpreting the THI result in agreement with the ICF. It is expected with this to help professionals and multidisciplinary teams in managing and directing the most appropriate treatments for cases of people with tinnitus.

\section{ANNEX 1}

\section{CIF COMPONENTS USED IN THE CONNECTION WITH THE}

\section{TINNITUS HANDICAP INVENTORY (THI)}

CIF CODE (b) BODY FUNCTIONS CIF CODE

b1149 Guidance functions, unspecified

b130 Energy and pulse functions 


\section{RECIMA21 - REVISTA CIENTÍFICA MULTIDISCIPLINAR ISSN 2675-6218}

LINKING TINNITUS HANDICAP INVENTORY - THI WITH THE INTERNATIONAL CLASSIFICATION OF FUNCTIONALITY, DISABILITY AND HEALTH - ICF: AN EXPLORATORY STUDY FOR THE APPLICATION OF THE LINKING RULES OF THE WORLD HEALTH ORGANIZATION

b1304 Control of impulses

b1341 Sleep onset

b1400 Maintaining attention

b 152 Emotional functions

b1520 Appropriateness of emotion

b 1521 Emotion regulation

b1522 Range of emotions

b1560 Auditory perception

b1602 Thought content

b1603 Thought control

b230 Hearing functions

b2400 Ringing in the ears

(d) ACTIVITY AND PARTICIPATION

d160 Focus attention

d166 Read

d177 Making decisions

d2401 Coping with stress

d640 Carrying out housework

d720 Complex interpersonal interactions

d750 Informal social relations

d760 Family Relations

d8451 Keeping a job

d920 Recreation and leisure

d9205 Socialization

p7 Interpersonal interactions *

p8 Major areas of life.*

\section{(e) ENVIRONMENTAL FACTORS}

e1252 Hearing Aid or Cochlear Implant 


\section{RECIMA21 - REVISTA CIENTÍFICA MULTIDISCIPLINAR ISSN 2675-6218}

LINKING TINNITUS HANDICAP INVENTORY - THI WITH THE INTERNATIONAL CLASSIFICATION OF FUNCTIONALITY, DISABILITY AND HEALTH - ICF: AN EXPLORATORY STUDY FOR THE APPLICATION OF THE LINKING RULES OF THE WORLD HEALTH ORGANIZATION Scheila Farias de Paiva

\section{Referências}

1. Dias, A., Cordeiro, R., \& Corrente, o. E. (2006). Uncomfortable causado pelo Tinnitus medido pelo Questionário de Gravidade. Rev Saúde Pública, 706-11

2. Dantas, DS. Biopsychosocial model in health care: reflections in the production of functioning and disability data. Fisioter. mov. Curitiba, v. 33, e003321, 2020.

Disponível em <http://www.scielo.br/scielo.php?script=sci_arttext\&pid=S010351502020000100220\&lng=en\&nrm=iso>. Acesso em 07 Dez. 2020. Epub Apr 06, 2020. https://doi.org/10.1590/1980-5918.033.ao21.

3. Farias N, Buchalla CM. (2005). A CLASSIFICATION Internacional de Funcionalidade, Inability e Saúde da OMS: Conceitos, Usos e Perspectivas. Revista Brasileira

4. Buchalla CM. CLASSIFICATION Internacional de funcionalidade, Inability e Saúde. Centro colaborador da Organização Mundial da Saúde para a Familia de Classificações Internacionais em Português. 3. ed. São Paulo: Editora da Universidade de São Paulo; 2020. Coordenação e tradução.

5. OMS. (2003). Organização Mundial da Saúde, CIF: CLASSIFICATION Internacional de Funcionalidade, Inability e Saúde. São Paulo: EDUSP.

6. Üstün, B. Of Functioning, Disability And Health-A Common Framework For Describing Health States. Summary measures of population health: Concepts, ethics, measurement and applications, p. 343, 2002.

7. Paiva SF, Dória LES, Santos LC, Santos TA, Vieira GSP. Uso da CIF na área de Audiologia: Uma Revisão Integrativa. Revista CIF Brasil, Revista CIF Brasil. 2021;13(1):58-68.

8. Craig W. Newman, PhD; Gary P. Jacobson, PhD; Jaclyn B. Spitzer, PhD Development of the Tinnitus Handicap InventoryArch Otolaryngol Head Neck Surg. 1996;122:143-148

9. Ferreira, P. E. A.; Cunha, F.; Onishi, E. T.; Branco-Barreiro, F. C. A.; Ganança, F. F. Tinnitus handicap inventory: adaptação cultural para o Português Brasileiro. Pró-Fono Revista de Atualização Científica, Barueri (SP), v. 17, n. 3, p. 303-310, set.-dez. 2005.

10. Cieza A, Fayed N, Bickenbach J, Prodinger B. Refinements of the ICF Linking Rules to strengthen their potential for establishing comparability of health information. Disabil Rehabil 2019; 41(5):574-583.

11. James,M; Banik,A. ICF-Based Analysis of Psychological and Functional Aspects of Tinnitus. International Journal of Health Sciences \& Research (www.ijhsr.org) 231 Vol.8; Issue: 11; November 2018

12. Bernardelli RS et al. Aplicação do refinamento das regras de ligação da CIF à Escala Visual Analógica e aos questionários Roland Morris e SF-36 Ciência \& Saúde Coletiva, 26(3):1137-1152, 2021

13. McCombe A; Bagukey,D;Coles, R; McKenna,L; McKinney,C \& Winder-Taylor,P. (2001) Clinic.Otorinolaringol. 26. 388-393

14. Tunkel, D. E., Bauer, C. A., Sun, G. H., Rosenfeld, R. M., Chandrasekhar, S. S., Cunningham, E. R., ... Whamond, E. J. (2014). Clinical Practice Guideline. Otolaryngology-Head and Neck Surgery,51(2_suppl), S1S40. doi:10.1177/0194599814545325

15. Costa, T.R.S. Distúrbios de audição e a CLASSIFICATION internacional de funcionalidade, inability e saúde. 2013. 111 f. Tese (Doutorado em Fonoaudiologia) Pontifícia Universidade Católica de São Paulo, São Paulo, 2013 


\section{RECIMA21 - REVISTA CIENTÍFICA MULTIDISCIPLINAR} ISSN 2675-6218

LINKING TINNITUS HANDICAP INVENTORY - THI WITH THE INTERNATIONAL CLASSIFICATION OF FUNCTIONALITY, DISABILITY AND HEALTH - ICF: AN EXPLORATORY STUDY FOR THE APPLICATION OF THE LINKING RULES OF THE WORLD HEALTH ORGANIZATION

16. Organização Mundial de Saúde. Assessment de Saúde e Deficiência: Manual do WHO Disability Assessment Schedule (WHODAS 2.0): OMS, 2015 